\title{
ALLELOPATHIC POTENTIAL AND PHYTOCHEMISTRY OF CAMBARAZINHO (Vochysia haenkeana (Spreng.) Mart.) LEAVES IN THE GERMINATION AND DEVELOPMENT OF LETTUCE AND TOMATO
}

\author{
POTENCIAL ALELOPÁTICO E FITOQUÍMICA DAS FOLHAS DE CAMBARAZINHO \\ NA GERMINAÇÃO E DESENVOLVIMENTO DE ALFACE E TOMATE
}

\author{
Elvia Silvia RIZZI ${ }^{1}$; Kelly Cristina Lacerda PEREIRA ${ }^{1}$; Clara Anne de Araujo ABREU²; \\ Bruno Carlos Feliciano de Lima SILVA² ${ }^{2}$ Richard Matheus FERNANDES ${ }^{2}$; \\ Ademir Kleber Morbeck de OLIVEIRA ${ }^{3}$; Rosemary MATIAS ${ }^{3}$ \\ 1. Pós doutoranda em Meio Ambiente e Desenvolvimento Regional, Uniderp, Campo Grande, MS, Brasil; 2. Graduando em Ciências \\ Biológicas, Uniderp, Campo Grande, MS, Brasil; 3. Professor, Doutor, Uniderp, Campo Grande, MS, Brasil. \\ akmorbeckoliveira@gmail.com
}

\begin{abstract}
The interference of chemicals in the germination and growth of plant species, known as allelopathy, is one of the main ways of eliminating competition for resources through the release of allelochemicals. The aim of this study was to determine the presence of secondary metabolites in extracts prepared from leaves of Vochysia haenkeana, evaluating their allelopathic action on the germination and seedling growth of lettuce and tomato. The plant material was collected in the Taboco region, Mato Grosso do Sul state, and after drying and grinding, underwent extraction with the use of water and ethanol, concentration of $200.0 \mathrm{~g} \mathrm{~L}^{-1}$. The method using an ultrasound bath was followed by maceration for $24 \mathrm{~h}$ in the refrigerator without the presence of light. The extracts were subjected to classical phytochemical analysis and the determination of $\mathrm{pH}$, electrical conductivity, soluble solids and allelopathic tests. For bioassays, the extracts were diluted at concentrations of 25.0, 50.0, 100.0 and $150.0 \mathrm{~g} \mathrm{~L}^{-1}$ and the experimental design was completely randomized. There was a reduction in the percentage and speed of germination at concentrations of 25.0 and $50.0 \mathrm{~g} \mathrm{~L} \mathrm{~L}^{-1}$ in both extracts. The seedling growth was also adversely affected, both in the germination chamber and in the greenhouse. These results are probably associated with the presence of different allelochemicals in the extracts, such as phenolic compounds and flavonoids, indicating that this species presented allelopathic action.
\end{abstract}

KEYWORDS: Allelochemicals; Vochysiaceae; Vochysia haenkeana; Secondary metabolites; Phenolic compounds; Flavonoids.

\section{INTRODUCTION}

An Agroforestry System (AFS) arrangement involves pasture associated with forest and nonforest species, in the same area and at the same time, managed in an integrated manner. This type of system is used to increase the production per unit area (RODRIGUES et al., 2007), with the potential to increase the efficiency of land use and other natural resources, resulting in greater productive diversity in the rural property (NEPOMUCENO; SILVA, 2009).

This type of system is being developed in many Brazilian regions and specifically in the state of Mato Grosso do Sul where, of nearly 36 million hectares of pasture, $5.8 \%$ are used in intercropping systems with forests (SILVA, 2003). The trend is increasing, because different pastures have been degraded or are in the process of degradation as a consequence of inadequate management. Indeed, it seems likely that the current land use systems cannot continue to be used to ensure the productive capacity of existing resources (LIMA et al., 2013).
Thus, the search for native tree species that can be used in silvopastoral systems is presented as having great potential, bringing economic and environmental benefits to producers and to society. In this context, a significant number of native plants of the Cerrado region and the South Pantanal are cited for this purpose (POTT; POTT, 2003).

However, for the use of native species, it is necessary to study the influence that allelochemicals that they produce and release into the environment may have on other species, as these can act positively or negatively, by inhibiting or stimulating the growth of other plants (RICE, 1984).

The main function of allelopathic compounds is to decrease or eliminate competition for resources. To this end, plants release chemical substances, but a compound which is toxic to one species may not be so to another (FUJ; HIRADATE, 2007). These substances are released into the environment by exudation through the roots, decomposition of plant parts, leaching and volatilization (FERREIRA, 2004). They may damage, for example, the assimilation of nutrients, 
photosynthesis and growth (PIÑA-RODRIGUES; LOPES, 2001).

To understand the effect of the release of substances into the environment, certain species that are more sensitive to secondary metabolites are used as target species to assess initially the potential of the studied species. Lettuce and tomato are often used as bioindicators, since they are sensitive to metabolites and exhibit rapid and uniform germination (FERREIRA; AQUILA, 2000; FERREIRA, 2004).

However, knowledge about native plants in silvopastoral systems and their allelopathic potential is needed. Because this kind of association can increase the profitability of the property or decrease the productivity of species used in pastures, it is necessary to evaluate the allelopathic potential of native species before introducing them into this type of system.

Among the Cerrado tree species is found Vochysia haenkeana (Spreng.) Mart., popularly known as cambarazinho or stick-yellow, belonging to Vochysiaceae family. It is a secondary species measuring 8-20 m, occurring in Mato Grosso do Sul and Mato Grosso states, used in construction, joinery and as firewood. As it is quite vigorous and fast-growing, it is used for urban forestry and reforestation, with great potential for use in silvopastoral activities (LORENZI, 2013).

In this context, this study aimed to determine the presence of secondary metabolites and to analyze the chemical characteristics of the extracts, as well as the action of the leaves on germination and initial growth of lettuce and tomato seedlings.

\section{MATERIAL AND METHODS}

\section{Collection}

The leaves of $V$. haenkeana were harvested by hand, using pruning shears and trimmer, directly from 12 matrices in the Cerrado region of Taboco, municipality of Corguinho $\left(19^{\circ} 49^{\prime} \mathrm{S} 54^{\circ} 50^{\prime} \mathrm{W}, 320\right.$ m. Alt.) Mato Grosso do Sul, Brazil, in September 2013. They were then placed in plastic bags and transported to the Research Laboratory of Environmental and Biodiversity Systems, Uniderp, Campo Grande, MS. After sorting, the material, with the elimination of damaged leaves, was dried $\left( \pm 27^{\circ} \mathrm{C}\right)$ for 72 hours and triturated in an industrial mill. The material was stored in a glass bottle, sealed, labeled and stored in the refrigerator until the preparation of the extracts.

\section{Preparation of extracts}

The aqueous extracts $\left(\mathrm{Ex}_{\mathrm{H} 2 \mathrm{O}}\right)$ and ethanol $\left(\mathrm{Et}_{\mathrm{OH}}\right), 200 \mathrm{~g} \mathrm{~L}^{-1}$ were prepared separately using an ultrasound bath (UNIDQUE ${ }^{\circledR}, 1450$ ) for two hours and kept at rest in the dark for another 48 hours in the refrigerator; they were subsequently filtered (glass funnel and cotton) in a volumetric flask. Starting from the crude filtrate $\left(200.0 \mathrm{~g} \mathrm{~L}^{-1}\right)$ the dilution was made in smaller concentrations, of 25.0, 50.0, 100.0 and $150.0 \mathrm{~g} \mathrm{~L}^{-1}$ (OLIVEIRA et al., 2011).

\section{Phytochemistry}

For the assays to detect the chemical constituents of the aqueous and ethanolic extract, $200.0 \mathrm{~g} \mathrm{~L}^{-1}$ of $V$. haenkeana leaves were subjected to phytochemistry analyzed by wet method by means of precipitation reactions and/or color change. The exception to this procedure was the analysis of saponins, determined using $1 \mathrm{~g}$ of dry extract of the leaves, with analyses executed in triplicate (MATOS, 2009).

The aqueous and ethanol extracts $(200.0 \mathrm{~g}$ $\mathrm{L}^{-1}$ ) were also subjected to analysis of $\mathrm{pH}$ ( $\mathrm{pH}$ DM20, Digimed), electrical conductivity (EC DM3, Digimed) and soluble solids concentration, determined using a digital refractometer (RTD- 45 Refractometer), with results expressed in Brix degrees corrected to $20^{\circ} \mathrm{C}$.

\section{Germination and growth bioassays}

Germination tests were conducted in Petri dishes of $7 \mathrm{~cm}$ diameter containing two germitest sheets as substrate, $5 \mathrm{~mL}$ of the extracts used in concentrations of 25.0, 50.0, 100.0, 150.0 and 200.0 $\mathrm{g} \mathrm{L}^{-1}$ in addition to control water and alcohol, with four replications for each concentration containing 25 seeds (lettuce and tomato). To standardize the nomenclature, lettuce cypselae were called seeds.

The plates were maintained in a growth chamber at $20{ }^{\circ} \mathrm{C}$ for lettuce seeds and $25{ }^{\circ} \mathrm{C}$ for tomato, with photoperiod of 12 hours of white light (four fluorescent lamps of $20 \mathrm{~W} \pm 660$ lux). After the start of the experiment, the plates were not wetted again. The counting of germinated seeds was carried out daily for 7 days, and it was considered that germinated seeds were those that had $2 \mathrm{~mm}$ of root protrusion.

For growth bioassays, $10 \mathrm{~mL}$ of extracts were used at concentrations of 25.0, 50.0, 100.0, 150.0 and $200.0 \mathrm{~g} \mathrm{~L}^{-1}$ and the control water and alcohol, with four replications for each concentration containing 10 pre-germinated seeds on two germitest sheets placed in transparent plastic boxes $(11 \times 11 \times 3.5 \mathrm{~cm})$. The boxes were 
maintained in a growth chamber at $20{ }^{\circ} \mathrm{C}$ for lettuce seeds and $25{ }^{\circ} \mathrm{C}$ for tomato, with photoperiod of 12 hours of white light (four fluorescent lamps of $20 \mathrm{~W}$ \pm 660 lux). The evaluation was performed 10 days after sowing, with plant height $(\mathrm{mm})$ being measured from the lowest point of the stalk to the above-ground apex and root length $(\mathrm{mm})$ being measured from the lowest point of the stalk to the meristematic apex of the root system.

Bioassays in the greenhouse were carried out on polystyrene trays, in concentrations of 50.0, 100.0 and $200.0 \mathrm{~g} \mathrm{~L}^{-1}$ (plant powder mixed with vermiculite substrate), and the control used only the vermiculite substrate. After mixing, the material was moistened with distilled water and left to rest for 48 hours. For seeding cells, 60 seeds of each species were used for each treatment, one seed per cell.

The aerial part of the emergence process was observed daily for 10 days, and after that period there was the measurement of root system and aerial part. In order to analyze the germination results, we calculated the percentage of germination $(\% \mathrm{G})$, average germination time (AGT) in days (VIEIRA; CAVALHO, 1994) and the germination speed index (GSI), performed by daily counting of germinated seeds (MAGUIRE, 1962). The experimental design was completely randomized with the results (aqueous extracts $\left[\mathrm{Ex}_{\mathrm{H} 2 \mathrm{O}}\right]$ and ethanol $\left[\mathrm{Et}_{\mathrm{OH}}\right]$ ) evaluated separately.

Statistical analysis of the results was performed using the statistical program Bioestat 5.0 at $5 \%$ probability and significance when it occurred, while the statistical analysis by ANOVA and Tukey test was performed at the level of $5 \%(p<0.05)$.

\section{RESULTS AND DISCUSSION}

The $\mathrm{pH}$ of the results obtained through the chemical analysis of the aqueous extract $\left(\mathrm{Ex}_{\mathrm{H} 2 \mathrm{O}}\right), \mathrm{pH}$ $=4.8$ and ethanol $\left(\mathrm{Ex}_{\mathrm{EtOH}}\right), \mathrm{pH}=5.0$ (Table 1) indicated that there was no influence of this on the germination and growth of seedlings, because only extreme values in acidity or alkalinity may mask the effect of chemical substances (FERREIRA; AQUILA, 2000). Rice (1984) also states that the lettuce is a species that shows little sensitivity to different ranges of $\mathrm{pH}$ and only $\mathrm{pH}$ values $\leq 3.0$ (acid) and $\geq 9.0$ (basic) can affect germination.

The $\mathrm{pH}$ determination reveals how acid or alkaline the analyzed sample is, and in this study, the acidity of extracts suggests the presence of phenolic derivatives such as phenolic acids and flavonoids (BORELLA; CARVALHO, 2011), classes of active ingredients found in the aqueous and ethanol extract of $V$. haenkeana leaves.

In studies of the aqueous extract of fresh leaves of Vochysia divergens Pohl, Oliveira et al. (2013) indicated $\mathrm{pH}$ of $4.3 \pm 0.3$, which did not interfere in the process of germination and seedling growth of lettuce and tomato, a result similar to those found for Vochysia haenkeana.

In relation to electric conductivity, the values obtained for the $\mathrm{Ex}_{\mathrm{H} 2 \mathrm{O}}$ extracts $(\mathrm{CE}=14.30$ $\left.\mu \mathrm{S} \mathrm{cm}{ }^{-1}\right)$ and $\mathrm{Ex}_{\mathrm{EtOH}}\left(\mathrm{EC}=12.21 \mu \mathrm{S} \mathrm{cm}^{-1}\right)($ Table 1) did not negatively influence the germination and seedling growth. Only electrical conductivity of more than $200.0 \mu \mathrm{S} \mathrm{s}^{-1}$ was negative for the germination of carrot and lettuce seeds as reported by Souza et al. (1999), when evaluating the hydroalcoholic extract of five plants (Melinis minutiflora P. Beauv., Hyparrhenia rufa (Nees) Stapf, Panicum maximum Jacq., Mucuna aterrima Piper \& Tracy Holland and Bambusa spp.).

Table 1. Results of phytochemical analysis of extracts $\left(\mathrm{Ex}_{\mathrm{H} 2 \mathrm{O}}\right.$ and $\left.\mathrm{Ex}_{\mathrm{EtOH}}\right)$ of Vochysia haenkeana leaves (200.0 $\left.\mathrm{g} \mathrm{L}^{-1}\right)$

\begin{tabular}{ccc}
\hline Secondary metabolites & Ex & E2O \\
\hline Phenolic compounds & +++ \\
Tannins & +++ & ++ \\
Flavonoids & ++ & ++ \\
Free coumarins & ++ & - \\
Alkaloids & +++ & + \\
Saponins* & + & - \\
Cardiac glycosides & + & + \\
pH & + & 5.0 \\
Electrical conductivity $\left(\mu \mathrm{S} \mathrm{cm}^{-1}\right)$ & 4.8 & 12.21 \\
Soluble solids $\left({ }^{\circ}\right.$ Brix at $\left.20^{\circ} \mathrm{C}\right)$ & 14.30 & 0 \\
\hline
\end{tabular}

*analysis of dry extract. $\mathrm{Ex}_{\mathrm{H} 2 \mathrm{O}}=$ aqueous extracts; $\mathrm{Ex}_{\mathrm{EtOH}}=$ ethanol extracts. Strongly positive (+++), moderately positive (++), weakly positive (+) and absence (-). 
From electrical conductivity values, it is possible to estimate the ionic strength (cations and anions) of the extract, and therefore, together with dissolved solids, estimate the osmotic potential (DIAS; MARCOS Filho, 1996; VOLL et al., 2003). For soluble solids, the values found in $\mathrm{Ex}_{\mathrm{H} 2 \mathrm{O}}$ and $\mathrm{Ex}_{\mathrm{EtOH}}$ extracts tended to zero, indicating that the osmotic potential of the extract did not interfere with the germination and growth of the target species.

Oliveira et al. (2013), working with $V$. divergens, found electrical conductivity values between 14.9 and $26.1 \mu \mathrm{S} \mathrm{cm}^{-1}$, in the water-ethanol extract, while the soluble solid values were 0.8 for both extracts, with the authors asserting that these values did not interfere in the process of germination or growth of the target species.

The results found in this study also indicate that the electrical conductivity of values presented for $V$. haenkeana are below those that could adversely affect the germination process and growth of seedlings of lettuce and tomato.

The phytochemical characterization of $\mathrm{Ex}_{\mathrm{H} 2 \mathrm{O}}$ and $\mathrm{Ex}_{\mathrm{EtOH}}$ extracts of $V$. haenkeana demonstrated that the $\mathrm{Ex}_{\mathrm{H} 2 \mathrm{O}}$ extract has seven classes of secondary metabolites and the $\mathrm{Ex}_{\mathrm{EtOH}}$, five. Phenolic compounds (greater intensity in two groups), tannins and flavonoids (medium intensity, two extracts) and cardiac glycosides and alkaloids (low intensity, two extracts), are present in both extracts and free coumarins (great intensity) and saponins (low intensity), just in the $\mathrm{Ex}_{\mathrm{H} 2 \mathrm{O}}$ extract.

The species of the genus Vochysia are rich in terpenoids, specifically the triterpenes (HESS; MONACHE, 1999), besides the occurrence of phenolic compounds, tannins and flavonoids (CARNEVALE NETO et al., 2011; SOUZA et al., 2014). Recently, Oliveira et al. (2013) detected tannins, flavonoids and coumarins in the fresh leaves of Vochysia divergens, in addition to phenolic compounds, a result similar to those found in this study for the leaves of $V$. haenkeana.

Phenolic compounds range from simple phenols to more complex structures such as flavonoids and tannins. They are considered potent inhibitors of seed germination, inhibiting shoot growth and elongation of roots (RICE, 1984). For Ferrarese et al. (2000), total phenols contribute to the reduction of root elongation, and decreased elasticity of the cell wall and the formation of lignin, in addition to blocking mitochondrial respiration (WEIR et al., 2004). Specifically, tannins and flavonoids are allelochemicals which cause direct and indirect effects on cell division and can be released under natural conditions, due to their watersoluble characteristics (RICE, 1984; FERREIRA; AQUILA, 2000).

According to Rice (1984), coumarins, alkaloids and tannins function as inhibitors of seed germination and plant growth. Allelopathic activity was not found for the cardiac glycosides in the literature, but there are records of their medicinal use for treating heart failure and intoxication, in the form of teas made from plants with the presence of cardiac glycosides, indicating its potential action (VICKERY; VICKERY, 1981).

The germination bioassays (Table 2 and 3 ) showed that both extracts of $V$. haenkeana, aqueous and ethanolic, interfered with the germination of lettuce and tomato seeds from the concentrations of $50.0 \mathrm{~g} \mathrm{~L}^{-1}$ when compared with the control, and at the concentration of $200.0 \mathrm{~g} \mathrm{~L}^{-1}\left(\mathrm{Ex}_{\mathrm{H} 2 \mathrm{O}}\right)$ there was no germination. The exception to this pattern was $\mathrm{Ex}_{\mathrm{H} 2 \mathrm{O}}$, at $25.0 \mathrm{~g} \mathrm{~L}^{-1}$, which negatively affected the tomato seeds' germination at this concentration.

Table 2. Germination (\%), germination speed index (GSI), average time of germination (ATG) in days of lettuce seeds in different extracts $\left(\mathrm{Ex}_{\mathrm{H} 2 \mathrm{O}}\right.$ and $\left.\mathrm{Ex}_{\mathrm{EtOH}}\right)$ of Vochysia haenkeana

\begin{tabular}{ccccccc}
\hline $\begin{array}{c}\text { Concentration } \\
\left(\mathrm{g} \mathrm{L}^{-1}\right)\end{array}$ & $\mathrm{Ex}_{\mathrm{H} 2 \mathrm{O}}$ & $\mathrm{Ex}_{\mathrm{EtOH}}$ & $\mathrm{Ex}_{\mathrm{H} 2 \mathrm{O}}$ & $\mathrm{Ex}_{\mathrm{EtOH}}$ & $\mathrm{Ex}_{\mathrm{H} 2 \mathrm{O}}$ & $\mathrm{Ex}_{\mathrm{EtOH}}$ \\
\hline 0 & $98 \mathrm{a}$ & $97 \mathrm{a}$ & $9.5 \mathrm{a}$ & $8.12 \mathrm{a}$ & $0.73 \mathrm{a}$ & $0.86 \mathrm{a}$ \\
25.0 & $94 \mathrm{a}$ & $89 \mathrm{ab}$ & $8.6 \mathrm{a}$ & $7.38 \mathrm{ab}$ & $0.80 \mathrm{a}$ & $0.90 \mathrm{a}$ \\
50.0 & $69 \mathrm{~b}$ & $83 \mathrm{~b}$ & $3.9 \mathrm{~b}$ & $6.32 \mathrm{~b}$ & $1.28 \mathrm{~b}$ & $0.98 \mathrm{~b}$ \\
100.0 & $50 \mathrm{~b}$ & $65 \mathrm{c}$ & $1.93 \mathrm{c}$ & $3.9 \mathrm{c}$ & $1.65 \mathrm{c}$ & $1.19 \mathrm{c}$ \\
150.0 & $16 \mathrm{bc}$ & $65 \mathrm{c}$ & $0.57 \mathrm{~d}$ & $3.58 \mathrm{c}$ & $1.75 \mathrm{~d}$ & $1.26 \mathrm{~d}$ \\
200.0 & $0 \mathrm{c}$ & $47 \mathrm{~d}$ & $0 \mathrm{~d}$ & $2.02 \mathrm{~d}$ & $0 \mathrm{e}$ & $1.49 \mathrm{e}$ \\
\hline
\end{tabular}

*Means followed by same letter in columns do not differ statistically among themselves by Tukey test (p>0.05).

Seed vigor, evaluated by GSI and AGT (Tables 2 and 3 ), also began to be negatively affected at concentrations of $50.0 \mathrm{~g} \mathrm{~L}^{-1}$ for both extracts, in lettuce seeds. For tomato seeds, seed germination was affected from $25.0 \mathrm{~g} \mathrm{~L}^{-1}$, indicating that this species is more sensitive to allelochemicals 
present; at higher concentrations, the seeds of both target species germinated in smaller number and took longer. This result is related to the fact that allelopathic substances may interfere with cell division, membrane permeability and activation of enzymes (WEIR et al., 2004).

Table 3. Germination (\%), germination speed index (GSI), average time of germination (ATG) in days of tomato seeds in different extracts $\left(\mathrm{Ex}_{\mathrm{H} 2 \mathrm{O}}\right.$ and $\left.\mathrm{Ex}_{\mathrm{EtOH}}\right)$ of Vochysia haenkeana

\begin{tabular}{ccccccc}
\hline $\begin{array}{c}\text { Concentration } \\
\left(\mathrm{g} \mathrm{L}^{-1}\right)\end{array}$ & \multicolumn{2}{c}{ Germination $(\%)$} & \multicolumn{2}{c}{ GSI } & \multicolumn{2}{c}{ ATG (days) } \\
\hline 0 & $\mathrm{Ex}_{\mathrm{H} 2 \mathrm{O}}$ & $\mathrm{Ex}_{\mathrm{EtOH}}$ & $\mathrm{Ex}_{\mathrm{H} 2 \mathrm{O}}$ & $\mathrm{Ex}_{\mathrm{EtOH}}$ & $\mathrm{Ex}_{\mathrm{H} 2 \mathrm{O}}$ & $\mathrm{Ex}_{\mathrm{EtOH}}$ \\
25.0 & $86 \mathrm{a}$ & $92 \mathrm{a}$ & $4.03 \mathrm{a}$ & $10.07 \mathrm{a}$ & $1.39 \mathrm{a}$ & $1.22 \mathrm{a}$ \\
50.0 & $63 \mathrm{~b}$ & $92 \mathrm{a}$ & $2.5 \mathrm{~b}$ & $4.24 \mathrm{~b}$ & $1.60 \mathrm{~b}$ & $1.39 \mathrm{~b}$ \\
100.0 & $25 \mathrm{c}$ & $51 \mathrm{~b}$ & $0.92 \mathrm{c}$ & $2.00 \mathrm{c}$ & $1.70 \mathrm{c}$ & $1.62 \mathrm{c}$ \\
150.0 & $5 \mathrm{~d}$ & $32 \mathrm{bc}$ & $0.18 \mathrm{c}$ & $1.21 \mathrm{~cd}$ & $1.75 \mathrm{~d}$ & $1.67 \mathrm{~d}$ \\
200.0 & $0 \mathrm{e}$ & $12 \mathrm{~cd}$ & $0 \mathrm{c}$ & $0.43 \mathrm{~d}$ & $0 \mathrm{e}$ & $1.75 \mathrm{e}$ \\
\hline
\end{tabular}

*Means followed by same letter in columns do not differ statistically among themselves by Tukey test (p>0.05).

The greatest effect was observed with the $\mathrm{Ex}_{\mathrm{H} 2 \mathrm{O}}$ extract (Tables 2 and 3 ) on the germination process in both lettuce and tomatoes, probably related to coumarins and saponins only present in the extract, because coumarins act on the cell membrane, modifying cell permeability (WEIR et al., 2004). The mechanism of action in saponins is not well studied, but it is known that the amphiphilic behavior of part of the structure with a lipophilic character (triterpene or steroid) and another with hydrophilic (sugar) of the saponins, and the ability to form complexes with steroids, protein and phospholipid membranes, enable several biological actions (SCHENKEL et al., 2001), such as hormonal imbalances acting on the cell membrane and changing its permeability (WEIR et al., 2004).

It can be observed that during the germination process (Tables 2 and 3) in a germination chamber, the tomato seeds were most affected by the extracts, indicating that this genus, belonging to the Solanaceae family, is more sensitive to secondary metabolites than lettuce seeds, from the Asteraceae family. The difference in behavior in germination is probably linked to the physiological processes of the target species, which respond differently to allelochemicals present.

Several studies report that secondary metabolites may adversely affect the process of seed germination. For example, there was inhibition of lettuce seed germination by an extract of Mimosa caesalpiniaefolia Benth (cinnamon) at concentrations of 0.1 and $1.0 \mathrm{~g} \mathrm{~L}^{-1}$, as reported by Piña-Rodrigues and Lopes (2001). Studies of lettuce seeds and beggartick (Plectranthus barbatus Andrews), showed that the aqueous extract of $P$. barbatus, at the concentration of $250.0 \mathrm{~g} \mathrm{~L}^{-1}$ significantly reduced the percentage of germination of lettuce (AZAMBUJA et al., 2010). Extracts of leaves of Eucalyptus grandis W. Hill at concentrations of 500.0, 750.0 and $1000.0 \mathrm{~g} \mathrm{~L}^{-1}$ also inhibited lettuce seed germination (SOUZA; CARDOSO, 2013).

According to Ferreira (2004), allelopathic substances often interfere in the germination speed index, which is exemplified by Comiotto et al. (2011), working with aqueous extract of Schinus terebinthifolius Raddi, observing a decrease in GSI among lettuce seeds at the concentration of $500.0 \mathrm{~g}$ $\mathrm{L}^{-1}$. In studies with extracts of Eucalyptus citriodora Hook and lettuce germination, a significant delay was noted in germination at all concentrations tested (2.5, 5.0, 10.0 and $\left.20.0 \mathrm{~g} \mathrm{~L}^{-1}\right)$ compared to control (FERREIRA et al., 2007).

Similar results were obtained in studies of aqueous extract of Artemisia annua L. with lettuce seeds, which showed that seed germination was affected and took longer (MAGIERO et al., 2009). However, Oliveira et al. (2014), working with ethanolic and aqueous extracts of leaves Pouteria ramiflora (Mart.) Radlk with the seeds of lettuce and tomato, observed no decrease in germination time at any of the tested concentrations.

Analyzing the root growth of tomato and lettuce (Tables 4 and 5), it was found that the two extracts in a germination chamber caused a reduction in the length of the primary root and aerial part, for all concentrations, from $25.0 \mathrm{~g} \mathrm{~L}^{-1}$, except for the treatment $\mathrm{Ex}_{\mathrm{EtOH}}$, with tomato stem, which only showed a negative effect from the concentration of $50.0 \mathrm{~g} \mathrm{~L}^{-1}$.

For the experiment in a greenhouse (Table 5), there was also a reduction in the length of seedlings of lettuce and tomato, from the concentration of $50 \%$, except in the lettuce root system, affected at concentrations from $100 \%$. 
Table 4. Mean values of length $(\mathrm{mm})$ of the aerial part and roots of lettuce and tomato seedlings under different concentrations of extracts $\left(\mathrm{Ex}_{\mathrm{H} 2 \mathrm{O}}\right.$ and $\left.\mathrm{Ex}_{\mathrm{EtOH}}\right)$ of Vochysia haenkeana leaves, cultivated in a growth chamber

\begin{tabular}{ccccccccc}
\hline & \multicolumn{4}{c}{ Lettuce $(\mathrm{mm})$} & \multicolumn{3}{c}{ Tomato $(\mathrm{mm})$} \\
\hline $\begin{array}{c}\text { Concentration } \\
\left(\mathrm{g} \mathrm{L}^{-1}\right)\end{array}$ & \multicolumn{2}{c}{$\mathrm{Ex}_{\mathrm{H} 2 \mathrm{O}}$} & \multicolumn{2}{c}{$\mathrm{Ex}_{\mathrm{EtOH}}$} & \multicolumn{2}{c}{$\mathrm{Ex}_{\mathrm{EtOH}}$} \\
0 & Root & Stem & Root & Stem & Root & Stem & Root & Stem \\
25.0 & $55.9 \mathrm{a}$ & $3.9 \mathrm{a}$ & $16.4 \mathrm{a}$ & $6.8 \mathrm{a}$ & $60.6 \mathrm{a}$ & $24.4 \mathrm{a}$ & $51.8 \mathrm{a}$ & $18.6 \mathrm{a}$ \\
50.0 & $24.0 \mathrm{~b}$ & $3.2 \mathrm{~b}$ & $4.8 \mathrm{~b}$ & $1.9 \mathrm{~b}$ & $26.0 \mathrm{~b}$ & $20.4 \mathrm{~b}$ & $39.3 \mathrm{~b}$ & $19.7 \mathrm{a}$ \\
100.0 & $3.2 \mathrm{c}$ & $2.1 \mathrm{c}$ & $2.8 \mathrm{~b}$ & $1.5 \mathrm{~b}$ & $6.4 \mathrm{c}$ & $11.5 \mathrm{c}$ & $7.9 \mathrm{c}$ & $14.2 \mathrm{~b}$ \\
150.0 & $3.0 \mathrm{c}$ & $2.3 \mathrm{c}$ & $2.4 \mathrm{~b}$ & $1.5 \mathrm{~b}$ & $4.0 \mathrm{c}$ & $7.0 \mathrm{~d}$ & $5.5 \mathrm{c}$ & $12.6 \mathrm{~b}$ \\
200.0 & $3.0 \mathrm{c}$ & $1.4 \mathrm{~d}$ & $2.3 \mathrm{~b}$ & $1.2 \mathrm{~b}$ & $3.8 \mathrm{c}$ & $4.5 \mathrm{e}$ & $4.9 \mathrm{c}$ & $11.1 \mathrm{~b}$ \\
\hline
\end{tabular}

*Means followed by same letter in columns do not differ statistically among themselves by Tukey test (p>0.05).

Table 5. Mean values of length $(\mathrm{mm})$ of the aerial part and roots of lettuce and tomato seedlings under different concentrations of extracts $\left(\mathrm{Ex}_{\mathrm{H} 2 \mathrm{O}}\right.$ and $\left.\mathrm{Ex}_{\mathrm{EtOH}}\right)$ of Vochysia haenkeana leaves, cultivated in a greenhouse

Concentration $\left(\mathrm{g} \mathrm{L}^{-1}\right)$

$\begin{array}{cc}0 & 40.6 \mathrm{a} \\ 50.0 & 41.0 \mathrm{a} \\ 100.0 & 32.9 \mathrm{~b} \\ 200.0 & 8.8 \mathrm{c}\end{array}$

\section{Lettuce}

\begin{tabular}{cc} 
Root $-\mathrm{mm}$ & Stem $-\mathrm{mm}$ \\
$40.6 \mathrm{a}$ & $32.9 \mathrm{a}$ \\
$41.0 \mathrm{a}$ & $27.4 \mathrm{~b}$ \\
$32.9 \mathrm{~b}$ & $25.6 \mathrm{~b}$ \\
$8.8 \mathrm{c}$ & $8.9 \mathrm{c}$ \\
\hline
\end{tabular}

Tomato

$\begin{array}{cc}\text { Root }-\mathrm{mm} & \text { Stem }-\mathrm{mm} \\ 51.7 \mathrm{a} & 38.2 \mathrm{a} \\ 27.4 \mathrm{~b} & 16.2 \mathrm{~b} \\ 14.4 \mathrm{c} & 10.6 \mathrm{c} \\ 7.2 \mathrm{~d} & 4.6 \mathrm{~d}\end{array}$

*Means followed by same letter in columns do not differ statistically among themselves by Tukey test (p>0.05).

The results indicate that the extracts have a strong allelopathic action also on seedling growth, even at lower concentrations. These effects are related to allelochemicals found in the leaves (Table 1 ), although it is not clear which are the most effective in suppressing growth. The higher concentrations of certain secondary metabolites in the aqueous extract, such as free coumarins, seem not to have caused an inhibitory effect in isolation, since the ethanol extract, which did not have this kind of metabolite, also had the same effect on restricting growth in seedlings.

The results are similar to other studies, as reported by Silveira et al. (2014), with aqueous extract of Araucaria angustifolia (Bertol.) Kuntze, which showed a decline in the length of the roots and stems at concentrations $(25.0,50.0,75.0$ and $100.0 \mathrm{~g} \mathrm{~L}^{-1}$ ) similar to those seen in this study. Furthermore, Oliveira et al. (2011) in a study conducted with fresh leaves of bacupari (Rheedia brasiliensis (Mart.) Planch. \& Triana) and lettuce seed germination, showed that the average length of the root system was negatively affected by all treatments (40.0, 80.0 120.0 and $\left.160.0 \mathrm{~g} \mathrm{~L}^{-1}\right)$ compared to the control.

Similar results were reported by Silveira et al. (2012a, b) working with aqueous extract of the leaves and bark of Mimosa tenuiflora (Willd.) Poir., noting that all extracts negatively affected growth, reducing the length of the roots and the length of the aerial part of lettuce, indicating its phytotoxic effect. As reported, these negative effects on growth may be related to the presence of coumarins and saponins, since these metabolites act on the cell membrane, changing its permeability. In addition, saponins also cause hormonal imbalances, interfering with plant growth, as well as acting directly on photosynthetic process or indirectly through effects on stomata. They also affect the respiratory process, among other effects (RICE, 1984; SOUZA Filho; ALVES, 2002; WEIR et al., 2004).

The allelopathic interference observed in this study may be linked to different classes of allelochemicals with defensive functions in the plant and their actions, together, can often cause an allelopathic effect (SOUZA Filho; ALVES, 2002). According to Rice (1984), one of the factors that hinder the allelopathic observation is the difficulty in separating the side effects from the primary causes. The cause and effect are sometimes difficult to understand, since the same substance may affect various physiological functions of the plant and 
reactions may be triggered by more than one allelochemical (SOUZA Filho; ALVES, 2002).

\section{CONCLUSION}

The leaves of Vochysia haenkeana species have a strong allelopathic effect, impacting both germination and seedling growth in lettuce and tomato.

\section{ACKNOWLEDGEMENTS}

The authors are grateful to the Conselho Nacional de Desenvolvimento Científico e
Tecnológico $(\mathrm{CNPq})$ for providing the Scientific Start-up Grant (PIBIC) and for the present research grant (PQ2) and the Coordenação de Aperfeiçoamento de Pessoal de Nível Superior (Capes), for the master's and doctoral scholarship. We would also like to thank the Pantanal Research Centre (CPP), National Institute of Science and Technology in the Wetlands (INAU), National Council for Scientific and Technological Development (CNPq/MCT), Technology of the state of Mato Grosso do Sul (FUNDECT) and the Uniderp for funding the GIP project (Grupo Interdisciplinar de Pesquisa).

\begin{abstract}
RESUMO: A interferência de substâncias químicas na germinação e/ou crescimento de espécies vegetais é denominada alelopatia e tem como uma das principais funções eliminar a competição por recursos através da liberação de compostos aleloquímicos. O objetivo deste trabalho foi determinar a presença de metabólicos secundários em extratos preparados com folhas de Vochysia haenkeana, avaliando sua ação alelopática na germinação e crescimento inicial de plântulas de alface e tomate. O material vegetativo foi coletado na região do Taboco, Mato Grosso do Sul e após secagem e trituração, sofreram extração com a utilização de água e etanol, na concentração de $200,0 \mathrm{~g} \mathrm{~L}^{-1}$. O método utilizado foi banho de ultrasson seguido de maceração por $24 \mathrm{~h}$ na geladeira sem a presença de luz. Os extratos foram submetidos a análise fitoquímica clássica e a determinação de $\mathrm{pH}$, condutividade elétrica, sólidos solúveis e testes alopáticos. Para os bioensaios, os extratos foram diluídos em concentrações de 25,0, 50,0 100,0 e 150,0 g L ${ }^{-1}$ e o delineamento estatístico utilizado foi o inteiramente casualizado. Ocorreu redução na percentagem e velocidade de germinação, a partir da concentração de 25,0 ou $50,0 \mathrm{~g} \mathrm{~L}^{-1}$, em ambos os extratos. O crescimento das plântulas também foi afetado de maneira negativa, tanto em câmara de germinação como em casa de vegetação. Estes resultados provavelmente estão associados a presença de diferentes aleloquímicos nos extratos, tais como compostos fenólicos e flavonoides, indicando que a espécie apresenta ação alelopática.
\end{abstract}

PALAVRAS-CHAVE: Aleloquímicos; Vochysiaceae; Vochysia haenkeana; Metabolitos secundários; Compostos fenólicos; Flavonoides.

\title{
REFERENCES
}

AZAMBUJA, N.; HOFFMANN, C. E. F.; NEVES, L. A. S.; GOULART, E. P. L. Potencial alelopático de Plectranthus barbatus Andrews na germinação de sementes de Lactuca sativa L. e de Bidens pilosa L. Revista de Ciências Agroveterinárias, Lages, v. 9, n. 1, p. 66-73, Feb. 2010.

BORELLA, J. C.; CARVALHO, D. M. A. Avaliação comparativa da qualidade de extratos de Calendula officinalis L. (Asteraceae) comercializados em farmácias de manipulação em Ribeirão Preto - SP. Revista Brasileira de Farmácia, Rio de Janeiro, v. 92, n. 1, p. 13-18, Mar. 2011.

CARNEVALE NETO, F.; PILON, A. C.; SILVA, D. H. S.; BOLZANI, V. S.; CASTRO-GAMBOA, I. Vochysiaceae: secondary metabolites, ethnopharmacology and pharmacological potential. Phytochemistry Reviews, Dordrecht, v. 10, n. 3, p. 413-429, Jun. 2011. http://dx.doi.org/10.1007/s11101-011-9213-5

COMIOTTO, A.; MORAES, D. M.; LOPES, N. F. Potencial alelopático de extratos aquosos de aroeira sobre germinação e crescimento de plântulas de alface. Scientia Agraria Paranaensis, Cascavel, v. 10, n. 3, p. 2331, Apr. 2011.

DIAS, D. C. F. S; MARCOS FILHO, J. Testes de condutividade elétrica para avaliação do vigor de sementes de soja (Glycine $\max$ (L.) Merrill). Scientia Agrícola, Piracicaba, v. 53, n. 1, p. 31-42, Jan./Apr. 1996. http://dx.doi.org/10.1590/S0103-90161996000100005 
FERRARESE, M. L. L.; SOUZA, N. E.; RODRIGUES, J. D.; FERRARESE FILHO. Ferulic acid uptake by soybean root in nutrient culture. Acta Physiologiae Plantarum, Scandinavian, v. 22, n. 2, p. 121-124, Mar. 2000.

FERREIRA, A. G. Interferência, competição e alelopatia. In: FERREIRA, A. G.; BORGHETTI, F. (Eds.). Germinação: do básico ao aplicado. Porto Alegre, Artemed. 2004. p. 251-262.

FERREIRA, A. G.; ÁQUILA, M. E. A. Alelopatia: uma área emergente da ecofisiologia. Revista Brasileira de Fisiologia Vegetal, Campinas, v. 12 (Edição Especial), n.1, p. 175-204, Jan./Apr. 2000.

FERREIRA, M. C.; SOUZA, J. R. P.; FARIA, T. J. Potenciação alelopática de extratos vegetais na germinação e no crescimento inicial de picão-preto e alface. Ciência e Agrotecnologia, Lavras, v. 31, n. 4, p. 1054-1060, Jul./Aug. 2007.

FUJII, Y.; HIRADATE, S. Allelopathy: new concepts \& methodology. Enfield: Science Publishers, 2007. 398 p.

HESS, S. C.; MONACHE, F. D. Divergioic acid, a triterpene from Vochysia divergens. Journal of the Brazilian Chemical Society, São Paulo, v. 10, p. 104-106, Mar./Apr. 1999. http://dx.doi.org/10.1590/s010350531999000200005

LIMA, P. R.; MALAVASI, U. C.; ECCO, M.; ROSSET, J. S. Espécies lenhosas nativas com potencial de uso em sistema silvipastoril em Mato Grosso do Sul. Revista Agrogeoambiental, Pouso Alegre, v. 5, n. 2, p. 6778, Aug. 2013.

LORENZI, H. Árvores brasileiras: manual de identificação e cultivo de plantas arbóreas do Brasil. 4ed. Brasil: Nova Odessa: Instituto Plantarum, v. 2, 2013. 384 p.

MAGIERO, E. C.; ASSMANN, J. M.; MARCHESE, J. A.; CAPELIN, D.; PALADINI, M. V.; TREZZI, M. M. Efeito alelopático de Artemisia annua L. na germinação e desenvolvimento inicial de plântulas de alface (Lactuca sativa L.) e leiteiro (Euphorbia heterophylla L.). Revista Brasileira de Plantas Medicinais, Botucatu, v. 11, n. 3, p. 317-324, Mar. 2009.

MAGUIRE, J. D. Speed of germination-aid in selection evaluation for seedling emergence and vigor. Crop Science, Madison, v. 2, n. 1, p. 176-177, Mar. 1962.

http://dx.doi.org/10.2135/cropsci1962.0011183X000200020033x

MATOS, F. J. A. Introdução a fitoquímica experimental. 3ed. Fortaleza: Edições UFC, 2009. 150 p.

NEPOMUCENO, A. N.; SILVA, I. C. Caracterização de sistemas silvipastoris da região noroeste do Estado do Paraná. Floresta, Curitiba, v. 39, n. 2, p. 279-287, Apr./Jun. 2009. http://dx.doi.org/10.5380/rf.v39i2.14556

OLIVEIRA, A. K. M.; RIBEIRO, J. W. F.; FONTOURA, F. M.; MATIAS, R. Leaf extract effects of Vochysia divergens on lettuce and tomato. Allelopathy Journal, Haryana, v. 31, n. 1, p. 129-138, Jan. 2013.

OLIVEIRA, A. K. M.; RIBEIRO, J. W. F.; MATIAS, R.; GUSMÃO, D. H.; PEREIRA, K. C. L. Potencial alelopático de folhas frescas de bacupari (Rheedia brasiliensis (Mart.) Planch. \& Triana) na germinação de alface. Revista Brasileira de Biociências, Porto Alegre, v. 9, n. 4, p. 550-553, Oct./Dec. 2011.

OLIVEIRA, A. K. M.; PEREIRA, K. C. L.; MULLER, J. A.; MATIAS, R. Análise fitoquímica e potencial alelopático das cascas de Pouteria ramiflora na germinação de alface. Horticultura Brasileira, Bahia, v. 32, n. 1, p. 41-47, Jan./Mar. 2014. http://dx.doi.org/10.1590/S0102-05362014000100007

POTT, A.; POTT, V. J. Plantas nativas potenciais para sistemas agroflorestais em Mato Grosso do Sul. Campo Grande: Embrapa Gado de Corte. Boletim Técnico, 2003. 9 p. 
PIÑA-RODRIGUES, F. C. M.; LOPES, B. M. Potencial alelopático de Mimosa caesalpinaefolia Benthc sobre sementes de Tabebuia alba (Cham.) Sandw. Floresta e Ambiente, Rio de Janeiro, v. 8, n. 1, p. 130-136, Jan./Dec. 2001.

RICE, E. L. Allelopathy. 2ed. New York: Academic Press, 1984. 422 p.

RODRIGUES, E. R. R.; CULLEN JR, L.; BELTRAMES, T. P.; MOSCOGLIATO, A. V.; SILVA, I. C. Avaliação econômica de sistemas agroflorestais implantados para recuperação de reserva legal no Pontal do Paranapanema, São Paulo. Revista Árvore, Viçosa, v. 31, n. 5, p. 941-948, Sep./Oct. 2007.

SANTANA, D. G.; MUSTAFA, P. C. V.; SILVA, R. M. G. Germination meansurements to evaluate allelopathic interactions. Allelopathy Journal, Haryana, v. 17, n. 1, p. 43-52, Jul./Aug. 2006.

SCHENKEL, E. P.; GOSMANN, G.; ATHAYDE, M. L. Saponinas. In: SIMÕES, C. M.; SCHENKEL, E. P.; GOSMANN, G.; MELLO, J. C. P.; MENTZ, L. A.; PETROVICK, P. R. Farmacognosia: da planta ao medicamento. 3ed. Porto Alegre: UFGRS/UFSC, 2001. p. 597-619.

SILVA, V. P. Sistemas silvipastoris em Mato Grosso do Sul - para que adotá-los? Campo Grande: Embrapa Gado de Corte. Boletim Técnico, 2003. 13 p.

SILVEIRA, P. F.; MAIA, S. S. S.; COELHO, M. F. B. Potencial alelopático do extrato aquoso de folhas de Mimosa tenuiflora (Willd.) Poir. na germinação de Lactuca sativa L. Bioscience Journal, Uberlândia, v. 28, n. 3, p. 472-477, May/Jun. 2012a.

SILVEIRA, P. F.; MAIA, S. S. S.; COELHO, M. F. B. Potencial alelopático do extrato aquoso de cascas de jurema preta no desenvolvimento inicial de alface. Revista Caatinga, Mossoró, v. 25, n. 1, p. 20-27, Jan./Mar., $2012 b$.

SILVEIRA, B. D.; HOSOKAWA, R. T.; NOGUEIRA, A. C.; WEBER, V. P. Atividade alelopática de Araucaria angustifolia (Bertol.) Kuntze na germinação e crescimento inicial de Lactuca sativa L. Ciência Florestal, Santa Maria, v. 24, n. 1, p. 79-85, Jan./Mar. 2014.

SOUZA, C. L. M.; MORAIS, V.; SILVA, E. R.; LOPES, H. M.; TOZANI, R.; PARRAGA, M. S.;

CARVALHO, G. J. A. Efeito inibidor dos extratos hidroalcóolicos de coberturas mortas sobre a germinação de sementes de cenoura e alface. Planta Daninha, Viçosa, v. 17, n. 2, p. 263-272, Nov. 1999.

SOUZA, V. M.; CARDOSO, S. B. Efeito alelopático do extrato de folhas de Eucalyptus grandis sobre a germinação de Lactuca sativa 1. (alface) e Phaseolus vulgaris 1. (feijão). Revista Eletrônica de Educação e Ciência, Avaré, v. 3, n. 2, p. 1-6, Mar. 2013.

SOUZA FILHO, A. P. S.; ALVES, S. M. Função dos agentes alelopáticos nas plantas. In: SOUZA FILHO, A. P. S.; ALVES, S. M. Alelopatia: princípios básicos e aspectos gerais. 1ed. Belém: Embrapa Amazônia Oriental, 2002. p. 49-78.

SOUSA, L. R. F.; SILVA, J. A.; VIEIRA, P. C.; COSTA, M. B.; SANTOS, M. L. DOS, SBARDELOTTO, A. B.; PESSOA, C. Ó.; MORAES, M. O.; MENEZES, A. C. S. Constituintes químicos das cascas do caule de Vochysia thyrsoidea Pohl. (Vochysiaceae) e avaliação das atividades citotóxica e inibitória frente as catepsinas B e K. Química Nova, São Paulo, v. 37, n. 2, p. 281-287, Oct. 2014.

VICKERY, M. L.; VICKERY, V. Secondary plant metabolism. Hong Kong: The Macmillan Press Ltd., 1981. $335 \mathrm{p}$.

VIEIRA, R. D.; CARVALHO, N. M. Testes de vigor em sementes. Jaboticabal: FUNEP, 1994. 164 p. 
VOLL, E.; BRIGHENTI, A. M.; GAZZIERO, D. L. P; ADEGAS, F. S. Relações entre germinação de sementes de espécies de plantas. Planta Daninha, Viçosa, v. 21, n. 1, p. 181-189, Aug. 2003.

WEIR, T. L.; PARK, S. W.; VIVANCO, J. M. Biochemical and physiological mechanisms mediated by allelochemicals. Current Opinion in Plant Biology, Philadelphia, v. 7, n. 4, p. 472-479, Aug. 2004. http://dx.doi.org/10.1016/j.pbi.2004.05.007 